\title{
SETDB1 wt Allele
}

National Cancer Institute

\section{Source}

National Cancer Institute. SETDB1 wt Allele. NCI Thesaurus. Code C51046.

Human SET DB1 wild-type allele is located within 1q21 and is approximately $38 \mathrm{~kb}$ in length. This allele, which encodes histone-lysine $\mathrm{N}$-methyltransferase, $\mathrm{H} 3$ lysine-9 specific 4 protein, plays a role in the methylation of histone $\mathrm{H} 3$ at lysine- 9 , a specific tag for epigenetic transcriptional repression. 